\title{
EVALUATION OF DOSE DELIVERY FOR TOTAL MARROW IRRADIATION USING IMAGING DATA OBTAINED WITH TOMOTHERAPY DEVICE
}

\section{Loginova A.A. ${ }^{1}$, Tovmasian D.A ${ }^{1.2}$., Chernyaev A.P.2, Kobyseva D.A. ${ }^{1}$, Lisovskaya A.O.' ${ }^{1}$ Nechesnyuk A.V.1}

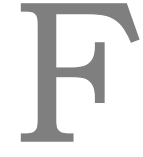

ractionated total marrow irradiation and lymphoid irradiation (TMLI) is a highly conformal method of radiotherapy, requiring a high degree of dose delivery accuracy. This study presents a quantitative assessment of the delivered dose while taking into account the influence of daily positioning using one patient receiving TMLI as an example.

Material and methods. Before each treatment session on TomoTherapy preliminary visualization is performed by megavoltage computer tomography (MVCT). The resulting images are used to correct the position of the patient and thereby to minimize the error of dose adjustment. In this study dose was recalculated for each treatment fraction, taking into account the current radiation geometry based on the MVCT images of the patient. The planned and delivered total dose distributions were compared.

Results. The difference between the delivered and planned average dose in target comprising bone marrow and lymphoid tissue was less than $0.5 \%$. The volume of the lungs, receiving a dose of 8 Gy did not exceed $39.3 \%$ of the total delivered dose, at the same time the coverage of the targets met prescribed requirements.

Discussion. Appropriate immobilization, visualization with subsequent correction of the patient's position prior to each fraction allowed for reliable and accurate dose delivery. The evaluation of the delivered dose provides opportunity for an objective analysis of the therapy.

Conclusion. The analysis of the delivered dose distribution based on MVCT visualization of the patient's body demonstrated the safety of TMLI method in terms of dose to the organs at risk, as well as the acceptable quality of the target coverage..

Keywords: TMI, TMLI, TomoTherapy, dose delivery, IMRT, MVCT.

Corresponding author: Loginova A.A., e-mail: aloginovaa@gmail.com

For citation: Loginova A.A., Tovmasian D.A., Chernyaev A.P., Kobyseva D.A., Lisovskaya A.O., Nechesnyuk A.V. Evaluation of dose delivery for total marrow irradiation using imaging data obtained with tomotherapy device. REJR 2021; 11(1):230-238. DOI: 10.21569/2222-7415-2021-11-1-230-237.

Received: $\quad 11.09 .20$

Accepted:

01.04.21

\section{ОЦЕНКА ТОЧНОСТИ ПОАВЕАЕНИЯ АОЗЫ ПРИ ТОТААЬНОМ ОБАУЧЕНИИ КОСТНОГО МОЗГА С ИСПОАЬЗОВАНИЕМ ААННЫХ ВИЗУААИЗАЦИИ НА AППAPATE TOMOTHERAPY}

\author{
Аогинова А.А. ${ }^{1}$, Товмасян А.А. ${ }^{2}$, Черняев А.П.2, Кобызева А.А. ', \\ Аисовская A.О' ${ }^{1}$, Нечеснюк А.В.'
}

1 - Dmitry Rogachev National Research Center of Pediatric Hematology, Oncology and Immunology.

2 - M.V. Lomonosov Moscow State University. Moscow, Russia.
1 - НМИЦ ДГОИ им. Дмитрия Рогачева МЗ РФ. г. Москва, Россия. 2 - ФГБОУ ВО «МГУ им. М.В. Аомоносова". г. Москва, Россия.

ракционированное тотальное облучение костного мозга и мимфоидной системы (ТОКМи $\Lambda$ ) является высоко-конформным методом кучевой терапии, требующим высокой степени точности доставки мечебной дозы. В работе представлен метод количественной оценки доставленной дозы с учетом влияния ежедневного позиционирования на примере пациента, получившего ТОКМи $\Lambda$. 


\section{RUSSIAN ELECTRONIC JOURNAL OF RADIOLOGY}

Материалы и методы. Перед каждым цечебным сеансом на аппарате TomoTherapy (Accuray Inc., Sunnyvale, CA, USA) проводится предварительная визуализация путем мегавоцьтной компьютерной томографии (МВКТ). Полученные изображения используются дмя коррекции положения пациента и, как следствие, дмя минимизации погрешности подведения дозы. В данной работе дмя каждой мечебной фракции поводимся перерасчет дозы с учетом текущей геометрии облучения на основе изображений МВКТ пациента, затем проводицось сравнение запланированной и доставленной дозы.

Результаты. Отклонение доставленной от запланированной средней дозы в мишени, вкцючающей костный мозг и мимфатические комлекторы, составимо менее 0,5\%. На распредемении доставленной дозы объем мегких, получивших дозу 8 Гр, не превышал 39,3\%, при этом покрытие мишени соответствовало установленным требованиям.

Обсуждение. Качественная иммобимизация, визуализация с последующей коррекцией положения пациента перед каждой фракцией позволили обеспечить надежную и точную доставку дозы. Оценка доставценной дозы дает возможность дия дальнейшей оптимизации схем мечения, объективного анализа терапии, прогноза возможных осложнений.

Выводы. Анализ полученного распределения дозы на основе визуализации МВКТ тела пациента показал безопасность применяемого метода ТОКМицС с точки зрения нагрузки на органы риска, а также удовлетворительного качества покрытия мишени.

КАючевые слова: тотальное облучение костного мозга, ТОКМ, тотальное обцучение костного мозга и мимфоидной системы, ТОКМи $А$, мучевая терапия с модуляцией интенсивности, $\Lambda$ ТМИ, ТомоТherapy, мегавольтная компьютерная томография, МВКТ.

Контактный автор: Аогинова А.А., e-mail: aloginovaa@gmail.com

Для иитирования: Аогинова А.А., Товмасян Д.А., Черняев А.П., Кобъзева Д.А., Аисовская А.О., Нечеснюк А.В. Оиенка точности подведения дозы при тотальном облучении костного мозга с использованием данных визуализаиии на аппарате tomotherapy. REJR 2021; 11(1):230-238. DOI: 10.21569/2222-7415-2021-11-1-230-237.

\section{Статья получена: $\quad 11.09 .20 \quad$ Статья принята: 01.04 .21}

\section{I}

\section{ntroduction.}

Total Body Irradiation (TBI) is widely used in conditioning programs before hematopoietic stem cell transplantation. The escalation of the TBI dose decreases recurrence rate, however, treatment-related mortality increases due to toxicity of radiotherapy [1-4]. This result negates the potential survival advantage of patients who received TBI with escalated doses. Some centers have begun to apply methods of Total Marrow Irradiation (TMI) using TomoTherapy (Accuray Inc., Sunnyvale, CA, USA) while reducing doses to organs at risk [5-8]. Unlike classical methods of TBI, the TomoTherapy device uses intensity-modulated radiation therapy (IMRT), which allows irradiation the target, while reducing the dose to sensitive normal tissues, such as lungs. The risks of using IMRT are associated with possible inaccuracies in dose delivery, due to sharp dose gradients near the boundary of target volume and the organs at risk. The proximity of dose gradients to these structures increases the risk of side-effects caused by uncertainty in patient positioning. Reliable methods for patient immobilization and positioning are crucial for accurate dose delivery and prevention of organs at risk damage.

At present time efforts are being made worldwide to introduce modern radiation therapy procedures for the treatment of hematologic malignant diseases, and the potential of TMI and total marrow and lymphoid irradiation(TMLI) is being studied in many centers around the world [911]. Pretreatment visualizations are currently a standard in the modern high conformal radiotherapy. Visualisation are usually performed before each fraction delivery on the TomoTherapy device, and the image results are used to correct position prior to treatment.

However, very little is known, how the patient's anatomy changes between fractions and 


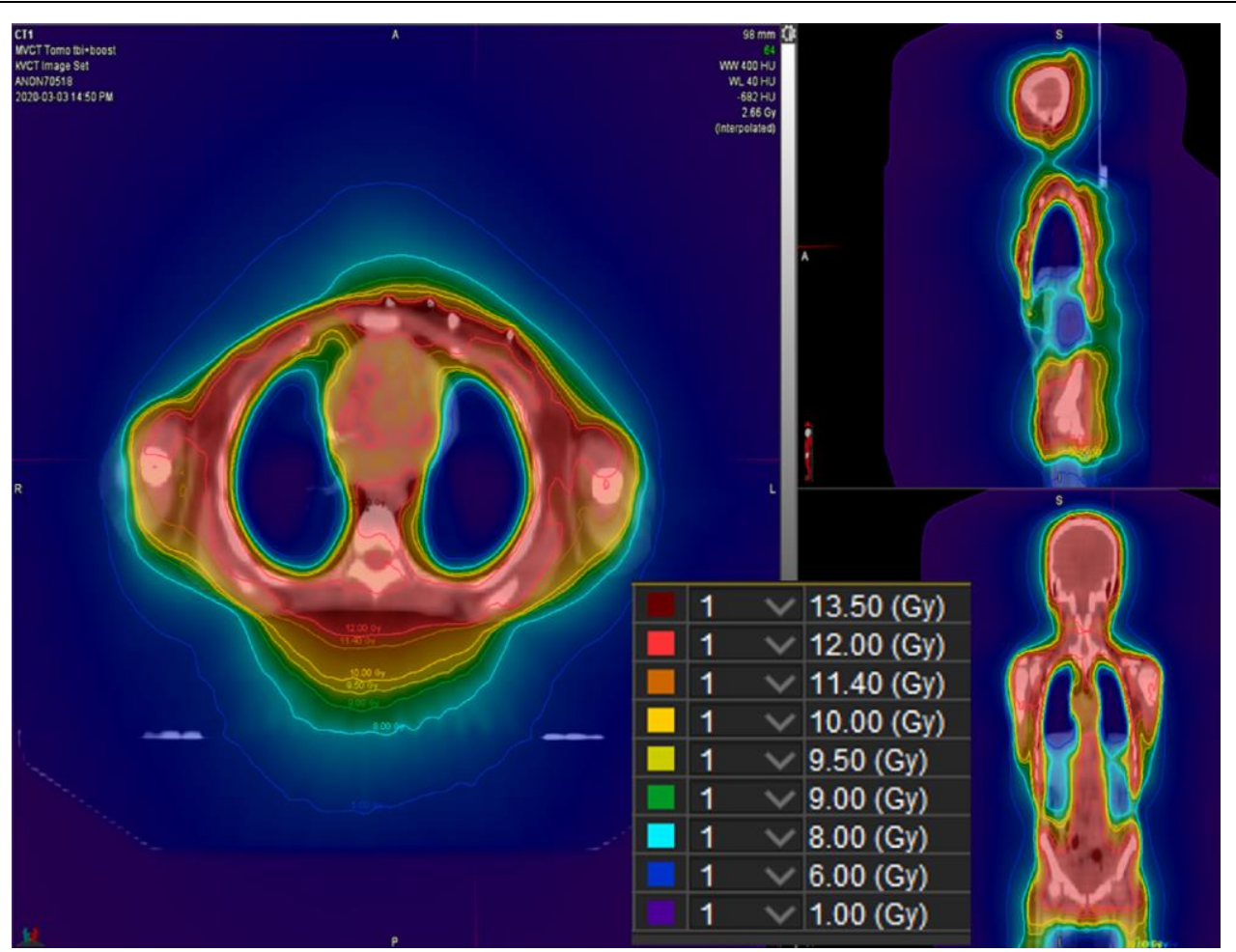

Fig. 1 a (Puc. 1 a)

Fig. 1 a. Planned dose distribution.

Рис. 1 а. Запланированное распределение Аозы.

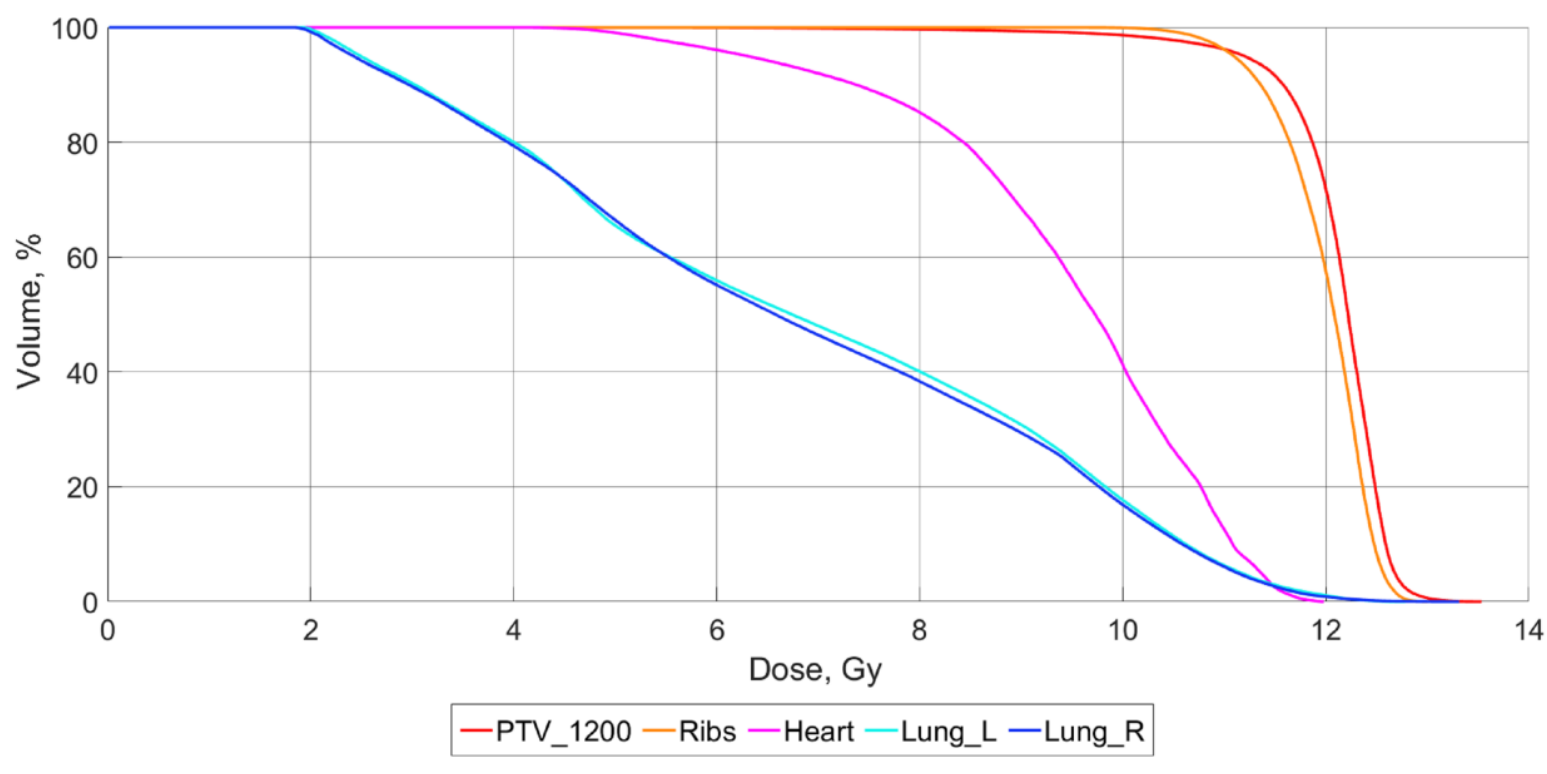

Fig. 1 b (Рис. 1 б)

\section{Fig. 1 b. Diagram.}

DVH for the left and right lung PTV_1200 including bone marrow and lymph nodes, Ribs, Heart, Lung_L and Lung_R, for the planned dose distribution.

\section{Рис. 1 б. Аиаграмма.}

Гистограммы доза-объем (ГДО) для планируемого объема мишени PTV_1200, вкАючающего костный мозг и мимфатические узмы, ребер (Ribs), сердца (Heart), мевого и правого мегкого (Lung_L и Lung_R), соответствующие запланированному распредемению дозы. 
how the patient's positioning errors affect dose delivery during TMLI course. In order to investigate this unmet clinical need, a method for quantitative assessment of the delivered dose is presented in this study. The overall purpose of this study is the evaluation of the TMLI method safety in terms of the dose to the organs at risk, as well as the quality of the target coverage.
TMLI. The spleen was excluded from the treatment. The Planned Target Volume (PTV_1200) included skeleton bones and lymphatic collectors with a symmetrical outer margin. Contouring of the target (PTV_1200), ribs (Ribs), and organs of risk, such as the lungs (Lung_R, Lung_L), kidneys (Kidney_R, Kidney_L), lenses (Lens_R, Lens_L), heart (Heart) on the planned CT-scans was per-

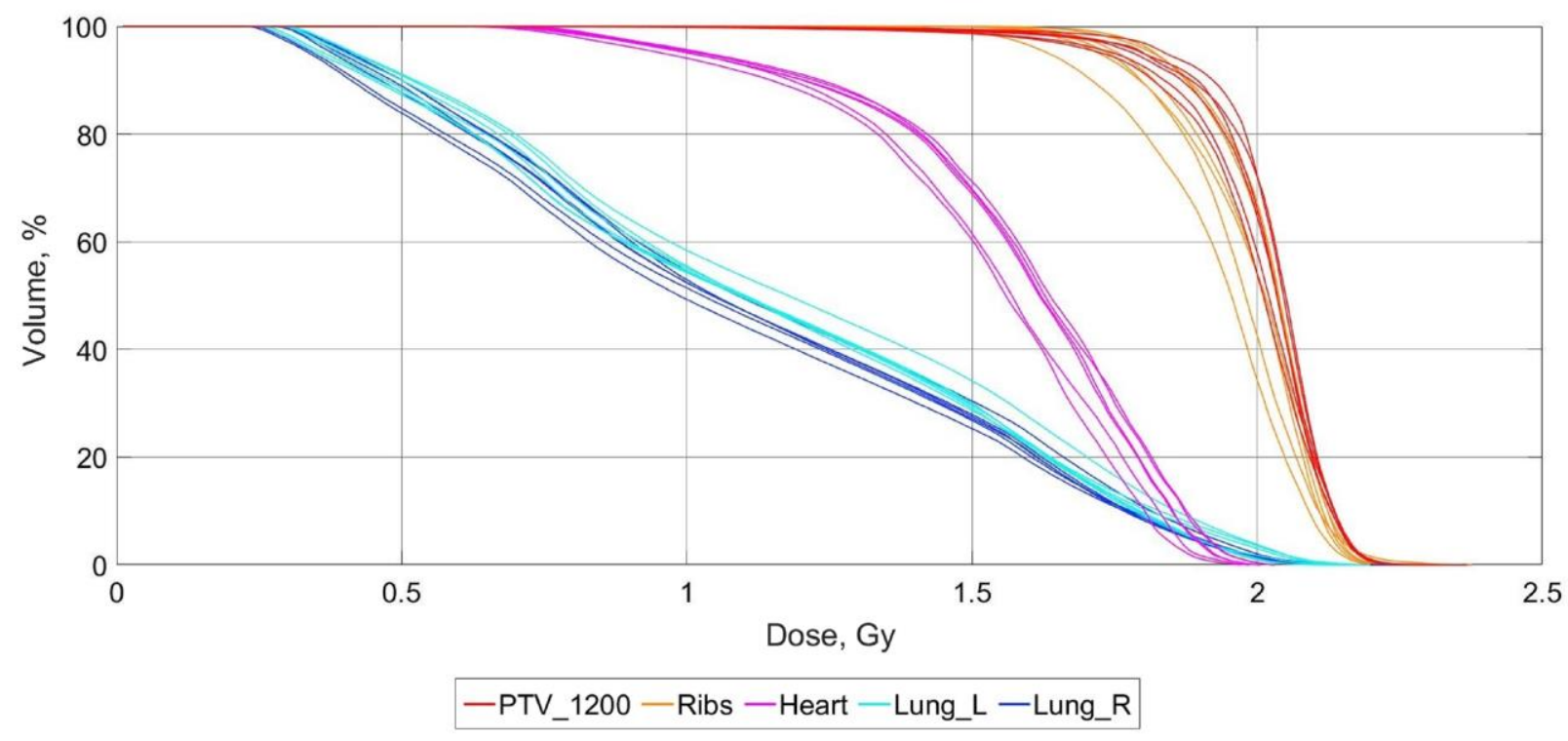

Fig. 2 (Puc. 2)

\section{Fig. 2. Diagram.}

DVH for the left and right lung PTV_1200 including bone marrow and lymph nodes, Ribs, Heart, Lung_L and Lung_R, for each of the 6 fractions..

\section{Рис. 2. Аиаграмма.}

Гистограммы доза-объем (ГДО) для планируемого объема мишени PTV_1200, включающего костный мозг и мимфатические узмы, ребер (Ribs), сердца (Heart), мевого и правого мегкого (Lung_L и Lung_R) coответствующие каждой из 6 мечебных фракций.

Materials and methods.

In this initial single patient study, we performed a quantitative assessment of the delivered dose during TBI while accounting for the positioning errors for each delivered fraction. A pediatric patient diagnosed with "Acute myeloid leukemia" with the radiation therapy required as part of a myeloablative conditioning regimen prior to bone marrow transplantation. In this particular case, a personalized approach to radiation therapy planning was required, due to a prior comprehensive treatment of retroperitoneal neuroblastoma completed a year ago., Specifically, prior treatment included high-dose chemotherapy followed by autologous hematopoietic stem cell transplantation and MIBG therapy (radionuclide therapy with methiodiobenzylguanidine). In addition he received local radiation therapy in the primary tumor region.

Taking into account prior treatment toxicity, we developed an individual prescription for formed.

The following prescribed planned doses were determined: PTV_1200 - total dose 12.0 Gy with a single fraction dose $2.0 \mathrm{~Gy}$, twice per day, 3 day total treatment. At least $90 \%$ of the PTV_1200 should receive dose of $11.4 \mathrm{~Gy}$, while at least $95 \%$ of the ribs should receive dose of $10 \mathrm{~Gy}$. At the same time, the volume of the lungs receiving dose of 8 Gy should not exceed $40 \%$. Furthermore the dose to the lenses, kidneys and heart should be minimized while maintaining the required target coverage.

The patient was immobilized using a vacuum mattress and a thermoplastic mask. For initial styling and verification of the patient's body position, a series of marks along the head, shoulder, chest, pelvis and legs were used. Images required for dosimetric planning were obtained using a LightSpeed RT16 Computer Tomograph (General Electric, Boston, USA), a scanning protocol with a slice thickness of $5 \mathrm{~mm}$ and $120 \mathrm{kV}$ tube voltage. 
Table №1. Comparative results of the DVH analysis for two cases - the planned dose distribution (plan) and the total delivered dose distribution for $\mathbf{6}$ fractions (sum).

\begin{tabular}{|c|c|c|c|c|c|c|c|c|c|}
\hline & & \multirow[b]{2}{*}{$\begin{array}{l}D_{\text {mean }} \\
\text { Gy }\end{array}$} & \multirow[b]{2}{*}{$\begin{array}{l}\mathbf{D}_{\min } \\
\mathbf{G y}\end{array}$} & & & \\
\hline & & & & $\begin{array}{l}D_{\max } \\
\text { Gy }\end{array}$ & $\begin{array}{l}\text { D50, } \\
\text { Gy }\end{array}$ & $\begin{array}{l}\text { D90, } \\
\text { Gy }\end{array}$ & $\begin{array}{l}\text { D95, } \\
\text { Gy }\end{array}$ & $\begin{array}{l}\text { D10, } \\
\text { Gy }\end{array}$ & $\mathrm{V8}, \%$ \\
\hline \multirow{2}{*}{$\begin{array}{l}\text { Lung_R } \\
\text { Правое } \\
\text { легкое }\end{array}$} & Sum(сумма) & 6,6 & 1,9 & 11,9 & 6,2 & 2,9 & 2,3 & 10,7 & 35,8 \\
\hline & Plan(план) & 6,8 & 2,1 & 11,6 & 6,6 & 3 & 2,4 & 10,6 & 38,4 \\
\hline \multirow{2}{*}{$\begin{array}{l}\text { Lung_L } \\
\text { Левое } \\
\text { легкое }\end{array}$} & Sum(сумма) & 6,8 & 2 & 12 & 6,7 & 2,9 & 2,3 & 10,9 & 39,3 \\
\hline & Plan(план) & 6,8 & 2,2 & 11,7 & 6,7 & 3 & 2,5 & 10,6 & 40 \\
\hline \multirow{2}{*}{$\begin{array}{l}\text { Heart } \\
\text { Сердще }\end{array}$} & Sum(сумма) & 9,4 & 5,1 & 11,6 & 9,6 & 7,2 & 6 & - & - \\
\hline & Plan(план) & 9,4 & 5,4 & 11,6 & 9,7 & 7,4 & 6,36 & - & - \\
\hline \multirow{2}{*}{$\begin{array}{l}\text { Ribs } \\
\text { Ребра }\end{array}$} & Sum(сумма) & 11,9 & 10,1 & 13 & 12 & 10,9 & 10,5 & - & - \\
\hline & Plan(план) & 12 & 10,8 & 12,7 & 12,1 & 11,3 & 11,1 & - & - \\
\hline \multirow{2}{*}{$\begin{array}{l}\text { PTV_1200 } \\
\text { PTV_1200 }\end{array}$} & Sum(сумма) & 12 & 9,9 & 13,1 & 12,2 & 11,2 & 10,7 & - & - \\
\hline & Plan(план) & 12,1 & 10,4 & 12,7 & 12,2 & 11,6 & 11,2 & - & - \\
\hline
\end{tabular}

Before each treatment session, preliminary imaging by megavoltage computed tomography (MVCT) was performed at TomoTherapy (Accuray) device. The resulting volumetric images of MVCT are used for preliminary verification and correction of patient position, with the objective to minimizes the errors in dose delivery. To accomplish this, rigid registrations of MVCT images with planning CT-scans are performed. Resulting differences in rigid registration are used to correct patient positioning by translational movement of the couch.

The translational shifts obtained during MVCT were applied in dose calculation for each of the 6 delivered fractions. Treatment plan was then calculated using the actual geometry of MVCT images using DQA software TomoTherapy (Accuray Inc., Sunnyvale, CA, USA). The calibration correction curve between Hounsfield units in MVCT and the corresponding densities of the human body was created and applied for dose calculation.

Deformable image registrations were performed in order to transfer contours from planning to MVCT images using MIM Maestro software (MIM Software Inc., Clevland, OH, USA). To minimize the subjective approach to contouring we used semi-automatic contouring methods devel- oped in the clinic, namely, pre-configured automated workflows. To minimize the subjective approach to contouring we used semi-automatic contouring methods developed in our clinic, namely, using pre-configured automated workflows. The planned and delivered (the sum of doses for all fractions) doses were compared by analyzing the dose-volume histograms (DVH).

\section{Results.}

The shifts detected during preliminary visualization did not exceed $5 \mathrm{~mm}$ in each direction and were corrected prior treatment by translational movement of the table. Thus, we investigated the effect on the dose delivery of the residual patient positioning errors caused by the changes in body geometry between each fraction. Figure 1a and $1 \mathrm{~b}$ correspond to the initial planned dose distribution and the DVH of the planned dose.

Figure 2 presents the DVH for the left and right lung, heart, ribs, and target, including bone marrow and lymph nodes for each of the 6 fractions, as the result of treatment plan recalculation in the geometry of MVCT images.

In the ribs area, the values of D70-D95 (the volume of structure, received specified dose) had the largest differenses relative to the average value or D10. This was expected as the volume of ribs 


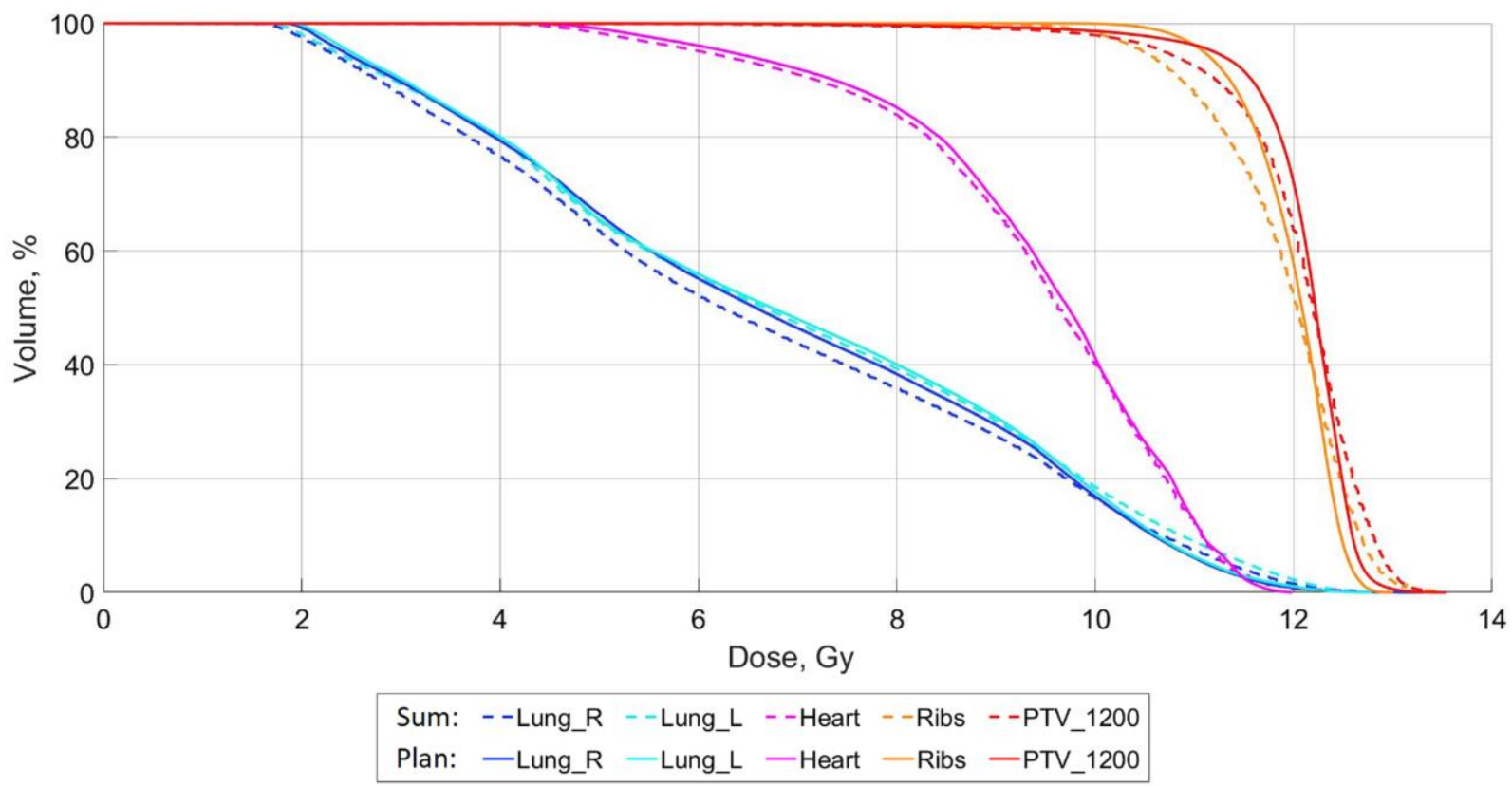

Fig. 3 (Pис. 3)

\section{Fig. 3. Diagram.}

Comparison of DVH for two cases - total delivered dose distribution for 6 fractions (Sum-dashed lines) and the planned dose distribution (Plan-solid lines).

\section{Рис. 3. Аиаграмма.}

Сравнение гистограмм доза-объем (ГДО) для двух случаев - шести фракций суммарного доставленного распределения дозы (Sum - прерывистые кинии) и запланированного распределения дозы (Plan - сплошные $и$ нии).

has a significant dose gradient as showed in Fig.1a. On the other hand, the lungs had the greatest dose differences for the mean (average) and maximum doses. This is consisted with the prior study D. Zuro et al. [11], noting that in TMI studies, the DVH of skeletal target regions at the D90, and the lungs at D10, should be critically evaluated to minimize uncertainties to improve on the overall accuracy and precision of the treatment.

Despite the observed differences in the dose delivered for each individual fraction, the average dose per fraction delivered to the PTV_1200 was within $1.25 \%$ of the planned fractional dose. This indicates that, the positioning error of volumetrically small regions, such as the neck or collarbone, will not have a significant impact on the average dose delivered to the PTV due to a small volume ration of this structures relative to the total PTV. However, in the case of a non-uniform distribution of tumor cells in combination with a systematically poor target coverage, these small areas can adversely affect the overall effect of the therapy.

Table 1 compares the DVH for the planned dose and the delivered dose obtained for sum of 6 fractions. Corresponding DVH are also compared in Figure 3. In the considered case, the residual positioning error brought about certain dosimetric consequences. However, due to the careful positioning and immobilization of the patient, this error had not a big values and was of a random nature, therefore, in the total for 6 fractions, we do not see significant changes between planned and total delivered DVHs (Fig. 3). The differences between the delivered from the planned average dose to PTV_1200 is less than $0.5 \%$. Dose values close to the minimum dose Dmin (dose received by at least $98 \%$ of the target volume) are less than planned where as dose values close to the maximum dose Dmax (maximum dose received by at least $2 \%$ of the target volume) are higher both for the target and in organs at risk.

When assessing the dose to the lungs, an important indicator is the volume of the lung tissue receiving a dose of $8 \mathrm{~Gy}$. According to the prescribed treatment regimen, this value should not exceed $40 \%$ (V8 $<40 \%$ ). With the exception of the single fraction for which this requirement was not met, and the volume of the left lung receiving a dose of 8 Gy was $42.5 \%$, this criterion did not exceed $39.3 \%$ in the total delivered dose distribu- 
tion. This implies that the main criterion $\mathrm{V} 8<40 \%$ of the quality and safety of the applied irradiation method is met for the overall treatment regimen.

At doses above $10 \mathrm{~Gy}$, the total delivered dose distribution in the lung region is higher relative to the planned dose due to the presence of high dose gradients in the immediate boundary of the lungs. In this case, the dose received by $10 \%$ of the lung volume differs from the planned dose by no more than 0.3 Gy.

In one of the fractions, the coverage of the ribs with the prescribed dose became worse, only $92,9 \%$ of ribs covered the dose of 10 Gy. However, considering the total sum plan, the coverage of the ribs with a dose of 10 Gy met the requirements of the prescription (Table 1). Obviously, errors in the patient's positioning negatively affected the quality of the target coverage. This scenario is taken into account using the concept of CTV and PTV. The reserve volume of the target, which is present when creating PTV based on CTV, allows to qualitatively perform irradiation of target cells located in the bone marrow and lymphatic collectors.

\section{Discussion.}

One of the main goals in modern TMLI is the dose reduction to the lungs in order to reduce the risk of developing interstitial pneumonia as side effect of the radiation therapy. Most of the current studies of the conditioning protocols toxicity, including TBI, use dosimetric data obtained using point dose calculations [12-14]. The use of point model of dose calculation leads to discrepancy in the actual delivered dose, not only between different clinics performing the procedure, but also within the same clinic, and generally results in challenges in assessing the tolerant doses to the lungs. Hui et al. [15] demonstrated that the classical methods of TBI are associated with a large spread in the dose distribution in patients, for example, part of the lung can receive a dose exceed-

\section{References:}

1. Clift R.A., Buckner C.D., Appelbaum F.R., Bryant E., Bearman,S.I., Petersen F.B. et al. Allogeneic marrow transplantation in patients with chronic myeloid leukemia in the chronic phase: a randomized trial of two irradiation regimens. Blood. 1990; 76: 1867-1871.

2. Clift R.A., Buckner C.D., Appelbaum F.R., Sullivan K.M., Storb $R$ TE. Long-term follow-Up of a Randomized Trial of Two Irradiation Regimens for Patients Receiving Allogeneic Marrow Transplants During First Remission of Acute Myeloid Leukemia. Blood 1998; 92 (4): 1455-1456.

3. Esiashvili N., Lu X., Ulin K., Laurie F., Kessel S., Kalapurakal $J$., et al. Higher Reported Lung Dose Received During Total Body Irradiation for Allogeneic Hematopoietic Stem Cell Transplantation in Children with Acute Lymphoblastic Leukemia Is Associated with Inferior Survival: A Report From the Children's Oncology Group. International Journal of Radiation Oncology, Biology, Physics. 2019; 104 (3): 513-521. DOI: 10.1016/j.ijrobp.2019.02.034. ing the prescribed dose by as much as $32 \%$.

Modern methods of radiation therapy based on IMRT allow three-dimensional dose calculation. Preliminary MVCT imaging allows to detect initial inaccuracies in the patient's position, which indicates the need for mandatory pretreatment visualization for this type of therapy. In order to avoid significant errors in dose delivery, it is necessary to adhere to the image guided radiation therapy protocol adopted by the clinic. Typically, such a protocol involves certain threshold bias values of the positioning shifts. If the positioning error exceed this value, the position of the patient must be corrected and patient should be re-scanned prior to the treatment. The method for calculating the dose based on MVCT images proposed in this study allows one to obtain more accurate assessment of delivered dose distribution within the patient relative to the planned dose distribution. This approach can lead to better understanding of what level of dose heterogeneity in the lungs is clinically significant. Further study can elucidate the correlation between the three-dimensional dose distribution and the frequency of pulmonary complications.

\section{Conclusion.}

The analysis of the delivered dose distribution based on MVCT visualization of the patient's body demonstrated the safety of TMLI method in terms of the dose to the organs at risk, as well as the satisfactory quality of the target coverage. Appropriate patient immobilization, positioning visualization with subsequent correction of the patient's position prior to each fraction allowed for reliable and accurate dose delivery. The study of the actual dose distribution for the TMLI provides opportunity for further optimization of the treatment regimens, while providing an objective analysis of the therapy, its potential complications and prediction of their occurrence.

4. Sampath S, Schultheiss T., Wong J. Dose response and factors related to interstitial pneumonitis after bone marrow transplant. International Journal of Radiation Oncology, Biology, Physics. 2005; 63 (3): 876-884. DOI: 10.1016/j.ijrobp.2005.02.032

5. Wong J., Liu A, Schultheiss T., Popplewell L., Stein A., Rosenthal J., et al. Targeted total marrow irradiation using threedimensional image-guided tomographic intensity-modulated radiation therapy: An alternative to standard total body irradiation. Biology of Blood and Marrow Transplantation. 2006; 12 (3): 306-315. DOI: 10.1016/j.bbmt.2005.10.026

6. Hui S., Kapatoes J., Fowler J., Henderson D., Olivera G., Manon R., et al. Feasibility study of helical tomotherapy for total body or total marrow irradiation. Medical Physics. 2005; 32 (10): 3214-3224. https://doi.org/10.1118/1.2044428

7. Schultheiss T., Wong J., Liu A., Olivera G, Somlo G. Imageguided Total Marrow and Total Lymphatic Irradiation Using Helical Tomotherapy. International Journal of Radiation Oncolo- 


\section{RUSSIAN ELECTRONIC JOURNAL OF RADIOLOGY}

gy, Biology, Physics. 2007; 67 (4): 1259-1267. DOI: 10.1016/j.ijrobp.2006.10.047

8. Corvo R., Zeverino M., Vagge S., Agostinelli S., Barra S., Taccini $G$., et al. Helical tomotherapy targeting total bone marrow after total body irradiation for patients with relapsed acute leukemia undergoing an allogeneic stem cell transplant. Radiotherapy and Oncology. 2011; 98 (3): 382-386. DOI: 10.1016/j.radonc.2011.01.016

9. Engellau J., Haraldsson A., Engström P., Lenhoff S. Implementation of Total Marrow Irradiation with Helical Tomotherapy; Clinical Experiences and Report on Organ Sparing in Pediatric Patients. International Journal of Radiation Oncology, Biology, Physics. 2018; 101 (4): 1006-1007. DOI: 10.1016/j.ijrobp.2018.01.080

10. Paix A., Antoni D., Waissi W., Ledoux M., Bilger K., Fornecker L., et al. Total body irradiation in allogeneic bone marrow transplantation conditioning regimens: A review. Critical Reviews in Oncology/Hematology. 2018; 123: 138-148. DOI: 10.1016/j.critrevonc.2018.01.011

11. Zuro D., Vagge S., Broggi S., Agostinelli S., Takahashi Y., Brooks J., et al. Multi-institutional evaluation of MVCT guided patient registration and dosimetric precision in total marrow irradiation: A global health initiative by the international consortium of total marrow irradiation. Radiotherapy and Oncology. 2019; 141: 275-282. DOI: 10.1016/j.radonc.2019.07.010

12. Briot E., Dutreix A., Bridier A. Dosimetry for Total Body Irradiation. Radiotherapy and Oncology. 1990; 18 (1): 16-29. DOI: 10.1016/0167-8140(90)90175-v

13. Van Dyk, J., Galvin, J.M., Glasgow, G.P., Podgorsak, E.B.: The physical aspects of total and half body photon irradiation. Task Group 29, Radiation Therapy Committee report. American Association of Physicists in Medicine Report No. 17. Radiotherapy and Oncology. 1987; 9 (2): 107-118.

14.Abugideiri M., Nanda R., Butker C., Zhang C., Kim S., Chiang $K$., et al. Factors Influencing Pulmonary Toxicity in Children Undergoing Allogeneic Hematopoietic Stem Cell Transplantation in the Setting of Total Body Irradiation-Based Myeloablative Conditioning. International Journal of Radiation Oncology, Biology, $\begin{array}{llll}\text { Physics. } 2016 ; & 94 & \text { (2): } 349-59 . & \text { DOI: }\end{array}$ 10.1016/j.ijrobp.2015.10.054

15. Hui S., Das R., Thomadsen B., Henderson D. CT-based analysis of dose homogeneity in total body irradiation using lateral beam. Journal of Applied Clinical Medical Physics; 2004; 5 (4): 71-79 DOI: 10.1120/jacmp.v5i4.1980. 